\title{
TRANSMISSIVITY VARIATIONS IN MUDSTONES
}

Alan M. MacDonald, Hydrogeologist, British Geological Survey, Murchison House, West Mains Road, Edinburgh, EH9 3LA, UK amm@bqs.ac.uk +44-131-6500389

Simon J. Kemp, Clay Mineralogist, British Geological Survey, Keyworth, NG12 $5 G G$ Nottingham, UK

Jeff Davies, Hydrogeologist, British Geological Survey, MacLean Building, Crowmarsh Gifford, Wallingford, Oxfordshire. OX10 8BB, UK.

\begin{abstract}
Many people in sub-Saharan Africa have to rely on meagre water resources within mudstones for their only water supply. Although mudstones have been extensively researched for their low permeability behaviour, little research has been undertaken to examine their ability to provide sustainable water supplies. To investigate the factors controlling the occurrence of usable ground water in mudstone environments, an area of Cretaceous mudstones in southeastern Nigeria was studied over a 3-year period. Transmissivity $(\mathrm{T})$ variations in a range of mudstone environments were studied. The investigations demonstrate that within the top $40 \mathrm{~m}$ of mudstones, transmissivity can be sufficient to develop village water supplies $\left(\mathrm{T}>1 \mathrm{~m}^{2} \cdot \mathrm{d}^{-1}\right)$. Transmissivity is controlled by two factors: low-grade metamorphism; and the presence of other, subordinate, lithologies within the mudstones. Largely unaltered mudstones (early diagenetic zone), comprising mainly smectite clays, are mostly unfractured and have a low $\mathrm{T}$ of $<0.1 \mathrm{~m}^{2} \cdot \mathrm{d}^{-1}$. Mudstones that have undergone limited metamorphism (late diagenetic zone) comprise mixed layered illite/smectite clays and ground water is found in widely spaced fracture zones $\left(\mathrm{T}>1 \mathrm{~m}^{2} \cdot \mathrm{d}^{-1}\right.$ in large fracture zones; $\mathrm{T}<0.1 \mathrm{~m}^{2} \cdot \mathrm{d}^{-1}$ away from fracture zones). Mudstones that have been further altered and approach the anchizone comprise illite clays, are pervasively fractured, and have the highest transmissivity values ( $\mathrm{T}$ $\left.>4 \mathrm{~m}^{2} \cdot \mathrm{d}^{-1}\right)$. Dolerite intrusions in unaltered, smectitic mudstones are highly fractured with transmissivity in the range $1<\mathrm{T}<60 \mathrm{~m}^{2} \cdot \mathrm{d}^{-1}$. Thin limestone and sandstone layers can also enhance transmissivity sufficiently to provide community water supplies.
\end{abstract}




\section{Introduction}

Mudstones have largely been overlooked as a source of sustainable ground water supplies. On hydrogeology maps they are defined as non-aquifers (Struckmier \& Margarat 1995) and most research has focused on their ability to retard ground water movement rather than as a source for water supply. In developed countries there is little need to use mudstones for water supply: water can be abstracted elsewhere and piped to the area of demand.

However, many of the world's poorest and most vulnerable people live in areas underlain by mudstones. In sub-Saharan Africa, approximately 70 million people live in rural communities underlain by mudstone (MacDonald \& Davies 2000). Often such people have few viable alternative sources of water and so have to rely on the meagre ground water resources available within their community. Even if money were available from an external agency to pipe water into an area underlain by mudstone, experience over the past 20 years has shown that using water resources within the community is generally much more sustainable (Black 1998). These factors, combined with the current poverty focus of aid, are increasing the amount of ground water development in mudstone areas.

This paper discusses the results of three years of research into ground water occurrence and development in a mudstone area in southeastern Nigeria. Factors controlling transmissivity variations within mudstones are described and discussed. The research has provided a framework for understanding how ground water may be found and abstracted from mudstones.

Transmissivity variations were chosen as a general indicator of the presence of developable ground water resources for village supplies since hydraulic conductivity values from fractured 
rocks have little meaning (Moore 1997). Using generally agreed principles for village supplies in sub-Saharan Africa (one borehole supplying 250 people with 25 litres per day), MacDonald and Davies (2000) demonstrated that transmissivity was the main factor determining borehole success or failure. If the transmissivity of the aquifer is greater than 1 $\mathrm{m}^{2} \cdot \mathrm{d}^{-1}$, a borehole equipped with a handpump can generally meet the demand over a 6-month dry season without drawdowns becoming excessive. The quality of the ground water is a separate issue and not discussed here.

\section{Research into the hydraulic properties of mudstones}

Although mudstones have not been considered as sources of water, they have been extensively researched for other reasons: their effect on ground water flow in sedimentary basins (e.g. Remenda 2001); their importance for storing hazardous wastes (Miller et al. 2000); the effect of mudstones on hydrocarbon migration (Neuzil 1986); and the effect of clays on limiting recharge to, and contamination of, major aquifers (Desbarats et al. 2001).

There are several findings from this large body of research that are relevant to this current study. Permeability is broadly related to porosity at a laboratory scale with laboratory tests indicating hydraulic conductivity from $10^{-16}$ to $10^{-8} \mathrm{~m} \cdot \mathrm{s}^{-1}$ (e.g. Neuzil 1994). The majority of field studies of mudstone permeability indicate hydraulic conductivities two to three orders of magnitude greater than laboratory estimates for shallow depths $\left(10^{-11}\right.$ to $\left.10^{-5} \mathrm{~m} \cdot \mathrm{s}^{-1}\right)$ but declining to laboratory levels a few 10 s of metres below ground surface (e.g. Sen \& Abbot 1991; Gautschi 2001; van der Kamp 2001). Field studies have also indicated that shallow fractures and interbedded siltstones, sandstones and limestones can all increase field permeability (Gerber et al. 2001; Capuano \& Jan 1996). 
Few of the mudstone studies report the clay mineralogy, but refer to the rocks as "clay" or "fractured clay". In this current study, more emphasis is placed on the effect of clay mineralogy, along with the presence of non-clay material, on transmissivity.

\section{The Oju/Obi study area}

An area in southeastern Nigeria was chosen as a study area to investigate the ground water potential of mudstones (Figure 1). The region covers two local government areas, Oju and Obi, which lie within Benue State. There are three different mudstone groups within Oju and Obi, ranging from soft mudstones to older, harder mudstones. Therefore the area is an excellent location for analysing ground water occurrence in different mudstone environments. The U.K. Department for International Development (DFID) had highlighted this area as a priority for aid, and in particular for improved water supply and sanitation. The British Geological Survey was commissioned to develop and undertake a programme of research into the ground water potential of the area. The knowledge and tools developed during this investigation were to be incorporated by WaterAid into a community water supply project for the area (Davies \& MacDonald 1999).

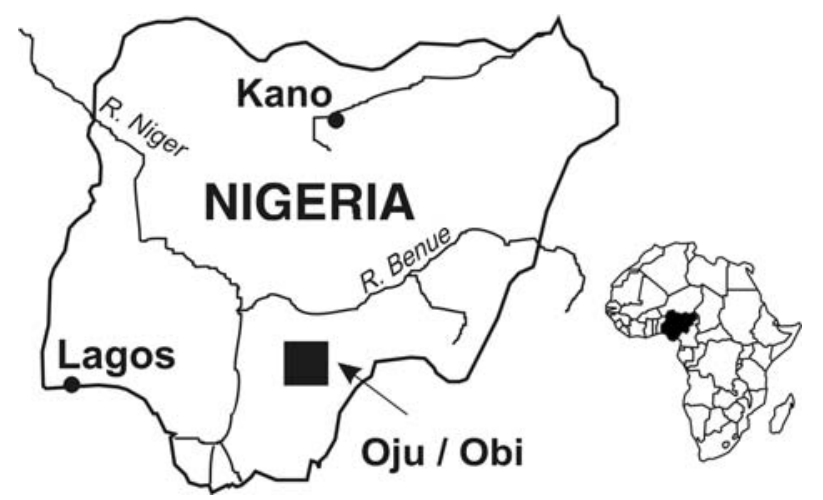

Figure 1 The location of the study area: $\mathrm{Oju} / \mathrm{Obi}$. 


\section{The water problem}

$\mathrm{Oju} / \mathrm{Obi}$ is a remote part of south-eastern Nigeria that experiences severe water shortages during the annual dry season. Mean annual rainfall is approximately $1600 \mathrm{~mm}$. The rainy season generally lasts from May to October, leaving six months with very little rainfall. During the dry season, unprotected ponds, seepages and hollows are the primary sources of domestic water. These sources become less reliable towards the end of the dry season and many fail altogether. Consequently, women and children have to walk long distances (often greater than $10 \mathrm{~km}$ ) to get limited supplies of generally poor quality water. Inevitably, much of the population of $\mathrm{Oju} / \mathrm{Obi}$ (approximately 300000 ) is badly affected by a variety of waterrelated illnesses, of which guinea worm, dysentery and malaria are endemic; outbreaks of cholera and typhoid are also common.

\section{Geology}

$\mathrm{Oju} / \mathrm{Obi}$ is situated in the lower section of the Benue Trough, a major elongated geological rift structure infilled with Cretaceous-age fine-grained, low permeability sediments deposited within a series of basins (Ofoegbu 1985). The sediments were deposited in deep- to shallowmarine and deltaic to fluviatile environments - often during periods of active tectonism. Parts of the sedimentary sequence have undergone low-grade metamorphism, and have been folded and faulted to varying degrees. Igneous rocks (mainly dolerite) have been intruded into the sediments. The environment of deposition and also the subsequent history of the rocks have a significant bearing on the water-bearing capacities of these low permeability rocks.

The lithologies and stratigraphical relationships of the sediments found in the $\mathrm{Oju} / \mathrm{Obi}$ area are outlined in Table 1 (Ojoh 1990). Their distribution is shown in Figure 2. 
Table 1 Stratigraphic sequence for the Oju/Obi area (adapted from Ojoh 1990).

\begin{tabular}{|c|c|c|c|}
\hline Age & Group & Formations & Description \\
\hline Maastrichtian & & & $\begin{array}{l}\text { Post Maastrichtian NW-SE } \\
\text { trending folding and faulting }\end{array}$ \\
\hline \multicolumn{4}{|l|}{ Campanian } \\
\hline Santonian & & & $\begin{array}{l}\text { NE-SW trending elongate folds } \\
\text { and faulting; igneous intrusions }\end{array}$ \\
\hline Coniacian & $\begin{array}{l}\text { Awgu } \\
\text { Group }\end{array}$ & $\begin{array}{l}\text { Awgu Shale } \\
\text { Formation } \\
\text { Agbani } \\
\text { Sandstone } \\
\text { Formation } \\
\end{array}$ & $\begin{array}{l}\text { Shaley carbonaceous } \\
\text { mudstones with thin shelly } \\
\text { limestones and sandstones } \\
\text { Fine to medium sandstones } \\
\text { with siltstones and mudstones }\end{array}$ \\
\hline Turonian & $\begin{array}{l}\text { Eze- } \\
\text { Aku } \\
\text { Group }\end{array}$ & $\begin{array}{l}\text { Eze-Aku } \\
\text { Shale } \\
\text { Formation } \\
\\
\text { Makurdi } \\
\text { Sandstone } \\
\text { Formation }\end{array}$ & $\begin{array}{l}\text { Shaley mudstones and } \\
\text { siltstone with thin sandstones } \\
\text { and limestones; can be divided } \\
\text { into Upper (younger than } \\
\text { Makurdi Sandstone Fm) and } \\
\text { Lower (older than the Makurdi } \\
\text { Sandstone Fm) } \\
\text { Fine to coarse sandstones with } \\
\text { siltstones and mudstone }\end{array}$ \\
\hline Cenomanian & & & Hiatus/unconformity \\
\hline $\begin{array}{c}\text { Upper } \\
\text { Albian } \\
\text { Lower }\end{array}$ & $\begin{array}{l}\text { Asu } \\
\text { River } \\
\text { Group }\end{array}$ & $\begin{array}{l}\text { Asu River } \\
\text { Formation } \\
\text { Metamor- } \\
\text { phosed Asu } \\
\text { River } \\
\text { Formation } \\
\end{array}$ & $\begin{array}{l}\text { Carbonaceous shaley } \\
\text { mudstone, limestone, } \\
\text { sandstone and siltstone } \\
\text { Pyroclastics and intrusives with } \\
\text { contact metamorphosed } \\
\text { mudstone, shale and } \\
\text { sandstone }\end{array}$ \\
\hline $\begin{array}{l}\text { Precambrian } \\
\text { Basement }\end{array}$ & & & $\mathrm{N}-\mathrm{S}$ trending faulting \\
\hline
\end{tabular}

Dolerite intrusions transect the area and are associated with both pre- and post-Turonian tectonic episodes. Although few are observed at outcrop, their presence throughout the northern part of the area is inferred from aeromagnetic maps (see Figure 2). Compressional folding began in Senonian times within the Benue Trough, forming a series of long, narrow folds parallel to the axis of the basin and producing anticlines more than $60 \mathrm{~km}$ long (Benkhelil 1989).

Prolonged exposure of the Cretaceous sediments to a sub-tropical climate has altered the nearsurface layers to a complex fersiallitic soil and associated weathered saprolite. Within this near-surface layer, an upper zone (1-5 m thick) contains a 1-3 m zone of iron and manganese 
nodules, sometimes consolidated into a ferricrete. This typically overlies several metres of weathered smectitic or illitic clays with subordinate kaolinite.
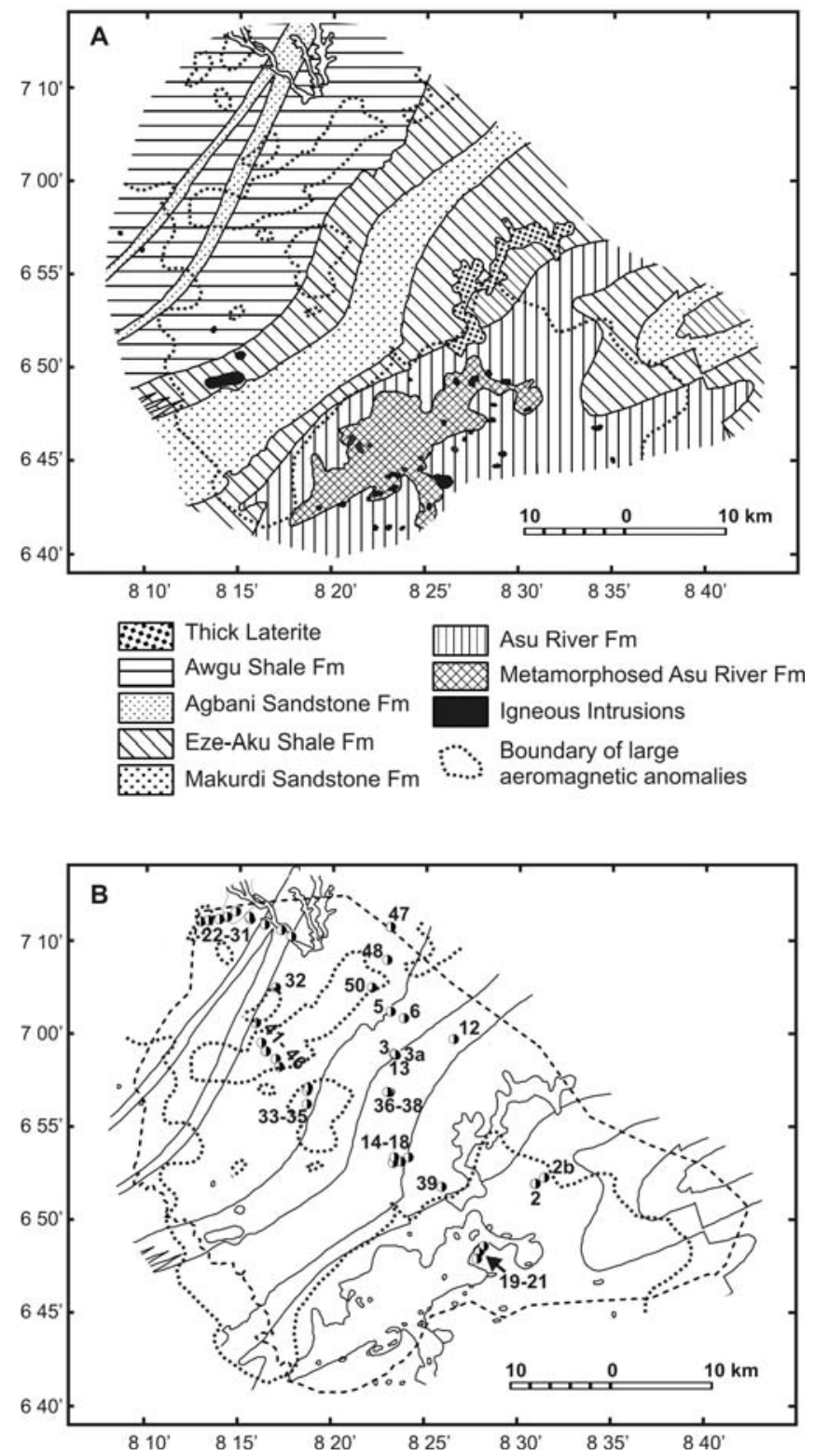

Figure 2. A: Geological map of the Oju/Obi area (based on Geological Survey of Nigeria 1957a, b) and B: Location of the exploratory boreholes (details in Table 2). 


\section{The ground water investigations}

Test sites were selected for each geological formation on the basis of lithology and also community vulnerability - the poorest communities being prioritised. Geophysical survey methods were used to ensure that boreholes were targeted to the correct lithology. Details of the geophysical surveys and interpretation are given in MacDonald et al. (2001). Forty-three test boreholes were drilled to depths greater than $15 \mathrm{~m}$, with a diameter of $170 \mathrm{~mm}$ Twentyfour of the boreholes penetrated only mudstone; 11 boreholes were sited in areas where mudstone was interbedded with thin limestone and sandstone layers; and 8 boreholes were targeted to small dolerite intrusions within the mudstones. These locations are shown in Figure 2B and details given in Table 2.

Rock chip samples were taken every $0.5 \mathrm{~m}$ and core samples from the deepest $3 \mathrm{~m}$ of the borehole. Core samples were lithologically logged using standard geological techniques (Tucker 1980). 116 samples from a total of 17 boreholes were collected for quantitative $<2$ $\mu \mathrm{m}$ clay mineral X-ray diffraction (XRD) analysis using standard methods. In order to gain further information about the nature of the clay minerals present in the samples, modelling of the $<2 \mu \mathrm{m}$ XRD profiles was carried out using Newmod-for-Windows ${ }^{\mathrm{TM}}$ software (Reynolds \& Reynolds 1996). Estimates of the smectite content of interlayered illite/smectite (I/S) were made by careful measurement of the position of the I/S 001/002 and 002/003 peaks (Moore \& Reynolds 1997). Kubler Indices of white mica crystallinity were calculated from the mean of five scans over the range $7.5-10.5^{\circ} 2$ theta at a speed of $0.5^{\circ} 2$ theta/minute using the machine recommendations of Kisch (1991). 
Table 2 Summary information from exploratory boreholes $>15 \mathrm{~m}$ deep.

\begin{tabular}{|c|c|c|c|c|c|c|c|c|c|c|}
\hline$B h I D$ & Location & $\begin{array}{l}\text { Geological } \\
\text { Formation }\end{array}$ & Depth (m) & $\begin{array}{c}\text { Major } \\
\text { lithology }\end{array}$ & Minor lithology & $\begin{array}{c}\text { Major } \\
\text { Fracture } \\
\text { zones } \\
\text { (mbgl) }\end{array}$ & $\begin{array}{c}\text { Main } \\
\text { water } \\
\text { inflows } \\
\text { (mbgl) }\end{array}$ & $\begin{array}{l}\text { Lithology } \\
\text { of major } \\
\text { inflow }\end{array}$ & $T\left(m^{2} \cdot d^{-1}\right)$ & Test type \\
\hline BGS19 & Oyinyi & Meta Asu River Fm & 41.5 & hard mudstone & thin quartzite & $10-15 ; 26-35$ & 14 & Mudstone & 6.5 & C-RATE \\
\hline BGS20 & Oyinyi & Meta Asu River Fm & 41 & hard mudstone & limestone/ash & $13-15 ; 31-34$ & $15 ; 36$ & Limestone & 27 & C-RATE \\
\hline BGS21 & Oyinyi & Meta Asu River Fm & 38.5 & hard mudstone & thin quartzite & $13-15$ & 14 & Mudstone & 3.0 & C-RATE \\
\hline BGS39 & Elim & Asu River Fm & 40.5 & compact mudstone & & $12-18$ & 15 & Mudstone & 4.0 & C-RATE \\
\hline BGS2 & Odubwo & Asu River Fm & 63.7 & compact mudstone & & $14-24$ & 20 & Mudstone & 4.1 & C-RATE \\
\hline BGS2b & Odubwo & Asu River Fm & 19.5 & compact mudstone & & $12-18$ & 12 & Mudstone & 3.5 & C-RATE \\
\hline BGS14 & Edumoga & Eze-Aku Shale Fm & 27.4 & mudstone & silty mudstone & none & dry & - & $<0.01^{\mathrm{a}}$ & - \\
\hline BGS15 & Edumoga & Eze-Aku Shale Fm & 29.5 & mudstone & silty mudstone & $14-18 ; 26-28$ & $15 ; 26$ & Mudstone & 1.6 & C-RATE \\
\hline BGS16 & Edumoga & Eze-Aku Shale Fm & 29.5 & mudstone & silty mudstone & $16-20 ; 26-29$ & 17 & Mudstone & 2.1 & C-RATE \\
\hline BGS17 & Edumoga & Eze-Aku Shale Fm & 29.5 & mudstone & silty mudstone & $12-29$ & 15 & Mudstone & 1.4 & C-RATE \\
\hline BGS18 & Edumoga & Eze-Aku Shale Fm & 53 & mudstone & silty mudstone & none & dry & - & $<0.01$ & - \\
\hline BGS5 & Ochingini & Eze-Aku Shale Fm & 23.4 & mudstone & & none & dry & - & $<0.01$ & - \\
\hline BGS6 & Ochingini & Eze-Aku Shale Fm & 19 & mudstone & limestone & $10 ; 16-19$ & 10 & Limestone & 18 & C-RATE \\
\hline BGS3 & Odaleko & Eze-Aku Shale Fm & 60.7 & mudstone & marl & none & dry & - & $<0.01$ & - \\
\hline BGS3a & Odaleko & Eze-Aku Shale Fm & 16 & mudstone & marl & none & dry & - & $<0.01$ & - \\
\hline BGS38 & Adum East & Makurdi Sandst Fm & 41.7 & mudstone & sandstone & none & dry & - & $<0.01$ & - \\
\hline BGS36 & Adum East & Makurdi Sandst Fm & 41.5 & sandstone & mudstone & 12 & $12 ; 21$ & Sandstone & 0.8 & C-RATE \\
\hline BGS37 & Adum East & Makurdi Sandst Fm & 18.5 & sandstone & mudstone & 8- 12 & 12 & Sandstone & 0.8 & C-RATE \\
\hline BGS12 & Ochingingi & Makurdi Sandst Fm & 15.7 & sandstone & mudstone & 9-11 13-15 & 10 & Sandstone & 1.0 & C-RATE \\
\hline BGS13 & Odaleko & Makurdi Sandst Fm & 87.5 & sandstone & mudstone & $78-82$ & 78.5 & Sandstone & 0.15 & SLUG \\
\hline BGS47 & Itogo & Awgu Shale Fm & 31.69 & soft mudstone & alluvium & none & dry & - & $<0.01$ & - \\
\hline BGS48 & Itogo & Awgu Shale Fm & 31.9 & soft mudstone & alluvium & none & 8 & Alluvium & 0.11 & SLUG \\
\hline BGS32 & Adega & Awgu Shale Fm & 32.5 & soft mudstone & marl & none & dry & - & $<0.01$ & - \\
\hline BGS22 & North Obi & Awgu Shale Fm & 23 & soft mudstone & & none & dry & - & $<0.01$ & - \\
\hline BGS23 & North Obi & Awgu Shale Fm & 23.5 & soft mudstone & & none & dry & - & $<0.01$ & - \\
\hline BGS24 & North Obi & Awgu Shale Fm & 23 & soft mudstone & & none & dry & - & $<0.01$ & - \\
\hline BGS25 & North Obi & Awgu Shale Fm & 21.3 & soft mudstone & & none & dry & - & $<0.01$ & - \\
\hline BGS26 & North Obi & Awgu Shale Fm & 23.4 & soft mudstone & marl, silt & none & 20 & Mudstone & 0.02 & SLUG \\
\hline BGS27 & North Obi & Awgu Shale Fm & 23.35 & soft mudstone & marl, silt & none & 18 & Mudstone & 0.08 & SLUG \\
\hline BGS28 & North Obi & Awgu Shale Fm & 23.4 & soft mudstone & marl, silt & none & dry & - & $<0.01$ & - \\
\hline BGS29 & North Obi & Awgu Shale Fm & 23.6 & soft mudstone & & none & dry & - & $<0.01$ & - \\
\hline BGS30 & North Obi & Awgu Shale Fm & 23.5 & soft mudstone & alluvium & none & 5 & Alluvium & 0.36 & SLUG \\
\hline BGS31 & North Obi & Awgu Shale Fm & 15 & soft mudstone & marl & none & dry & - & $<0.01$ & - \\
\hline BGS41 & Ugbodum & Awgu Shale Fm & 41.5 & soft mudstone & limestone & none & 29.5 & Limestone & 0.25 & SLUG \\
\hline BGS43 & Ugbodum & Awgu Shale Fm & 31.86 & soft mudstone & & none & dry & - & $<0.01$ & - \\
\hline BGS45 & Ugbodum & Awgu Shale Fm & 19.7 & soft mudstone & thin dolerite & $18-20$ & 18 & Thin dolerite & 0.2 & SLUG \\
\hline BGS42 & Ugbodum & Awgu Shale Fm & 32.05 & soft mudstone & thin dolerite & None & $15 ; 18$ & Thin dolerite & 0.8 & C-RATE \\
\hline BGS44 & Ugbodum & Awgu Shale Fm & 32 & soft mudstone & thin dolerite & $5-10$ & 5 & Thin dolerite & 0.1 & SLUG \\
\hline BGS34 & Adum West & Awgu Shale Fm & 39.5 & mudstone & dolerite & $34-39$ & 32 & dolerite & 4.0 & C-RATE \\
\hline BGS33 & Adum West & Dolerite & 18.5 & dolerite & mudstone & $15-18$ & 16.5 & dolerite & 51 & C-RATE \\
\hline BGS35 & Adum West & Dolerite & 21.5 & dolerite & & $15-21$ & 18 & dolerite & 23 & C-RATE \\
\hline BGS50 & Itogo & Dolerite & 31.75 & dolerite & soft mudstone & $15-17$ & 15 & dolerite & 2.0 & C-RATE \\
\hline BGS46 & Ugbodum & Dolerite & 32.07 & dolerite & mudstone & $8-10$ & 8 & dolerite & 45 & C-RATE \\
\hline
\end{tabular}

${ }^{a}$ Dry boreholes have been assigned a transmissivity of $<0.01 \mathrm{~m}^{2} . \mathrm{d}^{-1 .}$ 
Exploration boreholes that contained any ground water after drilling were developed and completed with $125 \mathrm{~mm}$ plastic screen. Only the upper $2 \mathrm{~m}$ were grouted to stop inflow from the shallow laterite layer and no gravel pack was installed; the boreholes were therefore effectively open hole. They were then test pumped to estimate the transmissivity. For boreholes where the yield estimated from airlifting was greater than approximately 0.1 $\ell . \mathrm{s}^{-1}$, constant rate tests using low yielding electrical pumps were undertaken (pumping rate 0.1 $\left.0.3 \ell . s^{-1}\right)$. For boreholes with considerably higher yields, Grundfos ${ }^{\circledR}$ submersible pumps were used. Boreholes were pumped for 5 hours and recovery data analysed using the Theis recovery method (Kruseman \& deRidder 1990). Where the yield of the borehole was estimated by airlifting to be less than $0.1 \ell^{-1} \mathrm{~s}^{-1}$, slug tests were carried out. This involved removing water over a 10-minute period and monitoring the recovery. The data were analysed numerically using BGSPT ${ }^{\mathrm{TM}}$ (Barker 1985; Barker \& Macdonald 2000) which accounts for non-instantaneous removal of water (Papadopulos \& Cooper 1967, Barker \& Herbert 1989; Mace 1999). In total 27 boreholes were tested; all tests were carried out towards the end of the dry season, when water-levels are at their lowest. Figure 3 shows examples of test data for a constant rate test and a slug test. Detailed information on the data and analysis is available in MacDonald (2001).

This experimental procedure allowed transmissivity values in the range $0.01-100 \mathrm{~m}^{2} . \mathrm{d}^{-1}$ to be measured. Since the purpose of the research was to investigate water supply from mudstones, detailed information on transmissivity values below $0.01 \mathrm{~m}^{2} \cdot \mathrm{d}^{-1}$ is unnecessary transmissivities greater than $1 \mathrm{~m}^{2} \cdot \mathrm{d}^{-1}$ are required to support a borehole with a handpump (see earlier). Boreholes with yields too low to be calculated from standard unpressurised slug tests were backfilled. To minimise data bias, dry boreholes were assigned a transmissivity value of $0.01 \mathrm{~m}^{2} \cdot \mathrm{d}^{-1}$. 

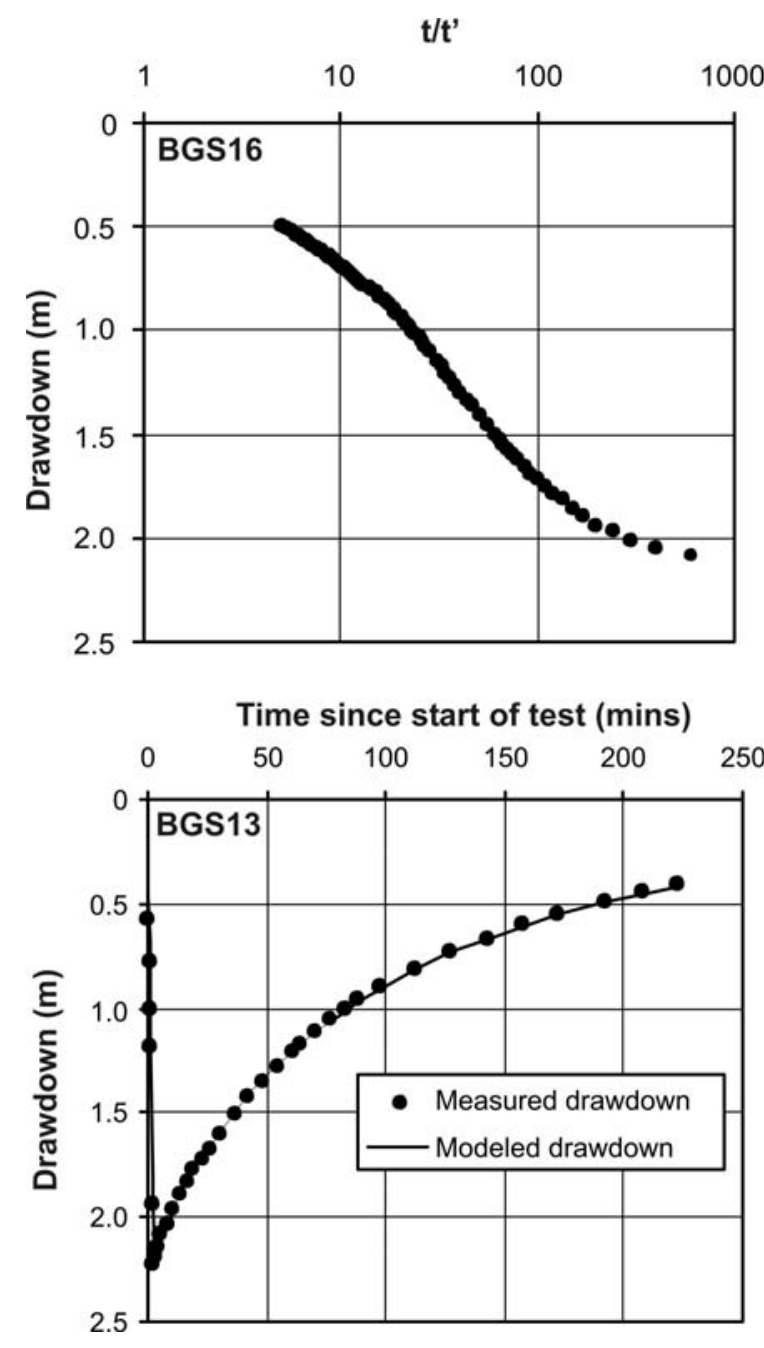

Figure 3 Examples of the pumping test data for Oju/Obi: BGS16 shows Theis recovery after 5 hours of pumping; BGS13 indicates drawdown and recovery for a slug test.

The slug test and Theis recovery methods applied above assume homogeneous and porous media - despite ground water flow in the rocks tested being primarily through fractures. Several key publications, however, have illustrated that fractured aquifers can be adequately analysed using these techniques, provided the borehole penetrates a representative sample of the aquifer, flow through the fractures is laminar and the time taken for water to diffuse from the matrix to the borehole is short (e.g. Snow 1968). Barker \& Black (1983) and Black (1985) took this further to demonstrate that, as a worst case scenario, errors in the value of 
derived transmissivity using homogeneous approaches are unlikely to exceed a factor of 2 . In media where transmissivity can vary by 4 or 5 orders of magnitude this error can be considered admissible. Further modelling (MacDonald 2001) indicated that these errors are only introduced if the time of diffusion across a matrix block, $b^{2} S_{s} / K_{m}$, was more than 0.01 day (where $b$ is the maximum distance to a fracture, $S_{s}$ is the specific storage of the matrix and $K_{m}$ is the hydraulic conductivity of the matrix).

\section{Results}

Representative borehole logs for each of the different units are shown in Figure 4. Detailed logs for each borehole are available in MacDonald (2001). Transmissivity measurements from the longest reliable dry season pumping test are shown in Table 2.

To test for systematic patterns in transmissivity, geometric means from the different hydrogeological units are compared in Table 3. For the purpose of the analysis, mudstone units within the Makurdi Sandstone Formation have been designated as the Eze-Aku Shale Formation. Also boreholes that penetrated very thin dolerite sills $(<1 \mathrm{~m})$ within the Awgu Shale Formation have been distinguished from boreholes penetrating larger dolerite intrusions.

Table 3 Summary of transmissivity data for the hydrogeological units in Oju/Obi.

\begin{tabular}{|c|c|c|c|c|}
\hline & \multicolumn{4}{|c|}{ Transmissivity $\left(\mathrm{m}^{2} \cdot \mathrm{d}^{-1}\right)$} \\
\hline & $\begin{array}{l}\text { No of } \\
\text { tests }\end{array}$ & Minimum $^{a}$ & maximum & $\begin{array}{c}\text { geometric } \\
\text { mean }\end{array}$ \\
\hline Metamorphosed Asu River Formation & 3 & 3.0 & 27 & 7.9 \\
\hline Asu River Formation & 3 & 2.5 & 4 & 3.3 \\
\hline Eze-Aku Shale Formation & 10 & $<0.01$ & 18 & 0.1 \\
\hline Makurdi Sandstone Formation & 5 & 0.1 & 1 & 0.37 \\
\hline Awgu Shale Formation & 11 & $<0.01$ & 0.25 & 0.02 \\
\hline Agbani Sandstone & 3 & $<0.01$ & 0.4 & 0.06 \\
\hline Thin dolerite in Awgu Shale & 3 & 0.06 & 0.8 & 0.17 \\
\hline Dolerite & 5 & 2.0 & 51 & 13 \\
\hline
\end{tabular}

${ }^{a}$ Dry boreholes have been assigned a transmissivity of $<0.01 \mathrm{~m}^{2} \cdot \mathrm{d}^{-1}$. 
Highest transmissivity values are found within the Metamorphosed Asu River Formation, the Asu River Formation and the larger dolerite intrusions. Lowest transmissivity values are found within the Awgu Shale Formation. Large variations in transmissivity are found within the Eze-Aku Shale Formation.

The detailed geological logs of the boreholes provide a first indication of why some boreholes have higher yields than others. For example, fractures at a depth of 12-35 m within both the Metamorphosed Asu River Formation and unmetamorphosed strata from the same formation are responsible for the high transmissivity measurements (see Table 2). The lack of open fractures within the Awgu Shale results in the very low transmissivity values. The geological logs show that the large range of measurements in the Eze-Aku Shale Formation is due to the presence of fractures in the mudstone, or thin bands of limestone. Boreholes that penetrate fracture zones have higher transmissivity than those with little evidence of fracturing. Where competent limestone is present (and fractured) transmissivity can be high; where limestone is absent, transmissivity is low.

However, the geological logs alone give little indication as to why some mudstone units are fractured (and therefore permeable) and some are not. In the following sections, the effect of two factors on transmissivity are discussed - low-grade metamorphism and the presence of other lithologies (such as thin sandstone layers or dolerite intrusions). 


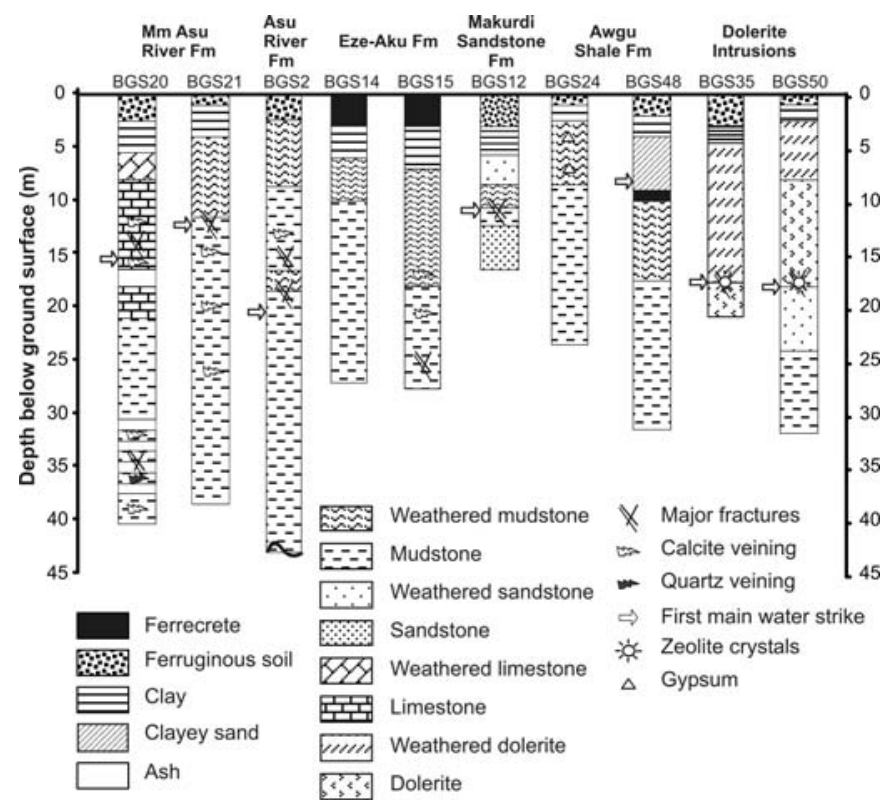

Figure 4 Representative borehole logs for each hydrogeological unit in Oju/Obi.

\section{Factors controlling transmissivity variations}

\section{Diagenesis and low-grade metamorphism}

The reaction series smectite $\rightarrow \mathrm{I} / \mathrm{S} \rightarrow$ illite $\rightarrow$ muscovite is indicative of irreversible, prograde transformation from diagenesis to low-grade metamorphism (Merriman \& Peacor 1999). Such changes are coupled with the expulsion of water and a regular pattern of increasing crystal size and crystal perfection which occurs from late diagenesis through to the epizone at temperatures up to $300{ }^{\circ} \mathrm{C}$. Temperature is the main driving force for these reactions but strain energy from tectonic stress may also be important. The classic study of Hower et al. (1976) from the US Gulf Coast first showed that smectite was replaced by I/S with an increasing proportion of illite layers as a function of increasing burial depth. While the presence of this reaction series is widely accepted, the nature and extent of the intermediate I/S remains controversial (Merriman \& Peacor 1999). The maturity chart shown 
in Figure 5 illustrates the expected clay mineralogy and physical properties of mudstones at various stages of diagenesis and low-grade metamorphism.

The clay mineralogy of representative mudstone boreholes in Oju/Obi is shown in Table 4 . To exclude the effects of tropical weathering, which can result in the alteration of a clay assemblage (e.g. Vicente et al. 1997), only the deepest, unweathered, samples from each borehole are considered.

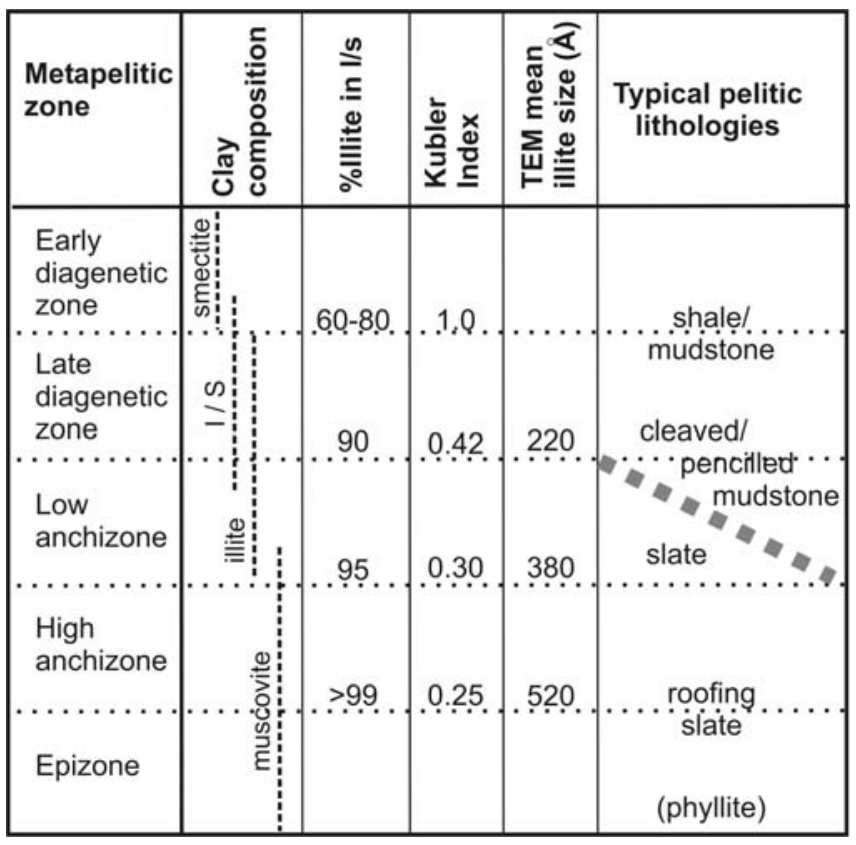

Figure 5 Metapelitic zones and indicators of smectite-I/S-illite-muscovite progress (after Merriman \& Peacor 1999).

The youngest mudstones, from the Awgu Shale Formation, have not undergone any significant burial and are still largely composed of unaltered smectite clay with minor kaolinite and traces of presumably detrital illite. The older Eze-Aku Group mudstones have been subjected to deeper burial and show a degree of fissility. NEWMOD-modelling of their I/S-dominated clay mineralogy suggests that the proportion of illite layers in the I/S increases with increasing burial (Table 4). These analyses are consistent with an earlier study of burial metamorphism in the Benue Trough (Akande \& Erdtmann 1998). 
Table 4 Clay mineralogy and low-grade metamorphism indicators for representative boreholes in $\mathrm{Oju} / \mathrm{Obi}$.

\begin{tabular}{|c|c|c|c|c|c|c|c|c|}
\hline \multirow{2}{*}{\multicolumn{2}{|c|}{ Exploratory Borehole }} & \multirow{2}{*}{$\begin{array}{c}\text { depth of } \\
\text { sample }(m)\end{array}$} & \multicolumn{4}{|c|}{ Composition of clay (\%) } & \multirow{2}{*}{$\begin{array}{c}\text { smectite in } \\
\text { I/S (\%) }\end{array}$} & \multirow{2}{*}{$\begin{array}{c}\text { Kubler } \\
\text { Index }(2 \theta)\end{array}$} \\
\hline & & & kaolinite & illite & smectite & $I / S$ & & \\
\hline \multicolumn{9}{|c|}{ Awgu Shale Formation } \\
\hline & BGS27 & 19.5 & 35 & 3 & 62 & 0 & 100 & \\
\hline & BGS31 & 5.25 & 23 & 1 & 76 & 0 & 100 & \\
\hline & BGS32 & 10.5 & 31 & 2 & 67 & 0 & 100 & \\
\hline \multicolumn{9}{|c|}{ Eze-Aku Shale Formation } \\
\hline \multirow[t]{3}{*}{ Upper } & BGS3a & 14.5 & 25 & 5 & 0 & 70 & 35 & - \\
\hline & BGS4 & 7.5 & 12 & 2 & 0 & 86 & 40 & - \\
\hline & BGS6 & 9.5 & 14 & 6 & 0 & - & 36 & - \\
\hline \multirow[t]{3}{*}{ Lower } & BGS15 & 9.5 & 6 & 3 & 0 & 91 & 29 & - \\
\hline & BGS16 & 9.5 & 1 & 6 & 0 & 93 & 25 & - \\
\hline & BGS18 & 9.5 & 12 & 6 & 0 & 82 & 32 & - \\
\hline \multicolumn{9}{|c|}{ Asu River Formation } \\
\hline & BGS2b & 17 & 16 & 84 & 0 & 0 & - & 0.53 \\
\hline & Akande et al. (1998) ${ }^{a}$ & \multicolumn{5}{|c|}{ illite clay } & - & 0.56 \\
\hline \multicolumn{9}{|c|}{ Metamorphosed Asu River Formation } \\
\hline & BGS19 & 8.5 & 38 & 49 & 13 & 0 & - & 0.18 \\
\hline & BGS21 & 4.5 & 30 & 65 & 5 & 0 & - & 0.37 \\
\hline
\end{tabular}

${ }^{a}$ Akande et al. (1998) analysed samples from nine different boreholes within the Benue Trough, $50 \mathrm{~km}$ from Oju/Obi

The clay mineralogy of the oldest mudstones, from the Asu River Group, is dominated by illite with minor kaolinite. The Kubler index of white mica crystallinity provides a measure of the crystal-size and order of illite crystals, and can be used as a useful indicator of the degree of low-grade metamorphism (Merriman \& Peacor 1999). Kubler indices of c.0.5 for the Asu River Formation indicate late diagenetic grades while lower values of 0.37 and 0.18 indicate higher-grade anchizonal and epizonal metamorphism respectively for the Metamorphosed Asu River Formation (Table 4). 
Figure 6 and Table 5 show the transmissivity values measured in boreholes penetrating the upper 20-40 m of mudstone, related to degree of low-grade metamorphism. Only boreholes that struck water within mudstone are included - all limestone, sandstone and dolerite boreholes have been omitted. It is clear that as metamorphism increases and the smectite content reduces, transmissivity increases. For unaltered, smectite-rich mudstones, transmissivity is consistently low. As metamorphism proceeds to the early/late diagenetic zone boundary, higher transmissivity values are possible since large fracture zones remain open; the variance remains high however, since transmissivity is still low away from the large fractured zones. Where metamorphism has proceeded well into, and beyond, the late diagenetic zone, the mudstones are sufficiently competent for widespread small fractures to remain open and transmissivity can be consistently high.

Table 5 Transmissivity and metamorphic indicators for the mudstone units in Oju/Obi. Boreholes in bold are those with measurements of clay mineralogy and metamorphic indicators.

\begin{tabular}{|c|c|c|c|c|}
\hline $\begin{array}{c}\text { Mudstone } \\
\text { unit }\end{array}$ & Boreholes & Transm & sivity $\left(m^{2} \cdot d^{-1}\right)$ & $\begin{array}{c}\text { Metamorphic indicators } \\
\text { (see table 4) }\end{array}$ \\
\hline Metamorphosed & BGS19, BGS21 & 4.4 & $3.0-6.5$ & Kubler Index $=0.18-0.37$ \\
\hline Asu River Fm & BGS2, BGS2b; BGS39 & 3.3 & $2.5-4.0$ & Kubler Index $=0.53-0.56$ \\
\hline \multicolumn{5}{|l|}{ Eze-Aku Shale Fm } \\
\hline Lower & $\begin{array}{l}\text { BGS14, BGS15, BGS16, } \\
\text { BGS17, BGS18 }\end{array}$ & 0.54 & $<0.01-2.0$ & $\%$ smectite in $\mathrm{I} / \mathrm{S}=28.7 \%$ \\
\hline Upper & BGS3, BGS3a, BGS5 & 0.01 & $<0.01$ & $\%$ smectite in I/S = 37\% \\
\hline Awgu Shale Formation & $\begin{array}{l}\text { BGS22, BGS23, BGS24, } \\
\text { BGS25, BGS26, BGS27, } \\
\text { BGS28, BGS29, BGS31, } \\
\text { BGS32 }\end{array}$ & 0.013 & $<0.01-0.08$ & $\%$ smectite in I/S = 0\% \\
\hline
\end{tabular}

The metamorphic model provides a major step towards understanding variations in transmissivity between different mudstone formations. Mudstones must be fractured to enhance their permeability sufficiently to be of use as an aquifer. Immature mudstones, that 
have not achieved late diagenetic grade metamorphism, still have a high component of smectite clay. Smectite-rich clays are plastic, easily deformed, and do not fracture easily. Any fractures that might be develop within the smectite can be quickly healed, either due to additional deformation or water absorption and swelling. Therefore, unaltered mudstones have little ability to transmit ground water.

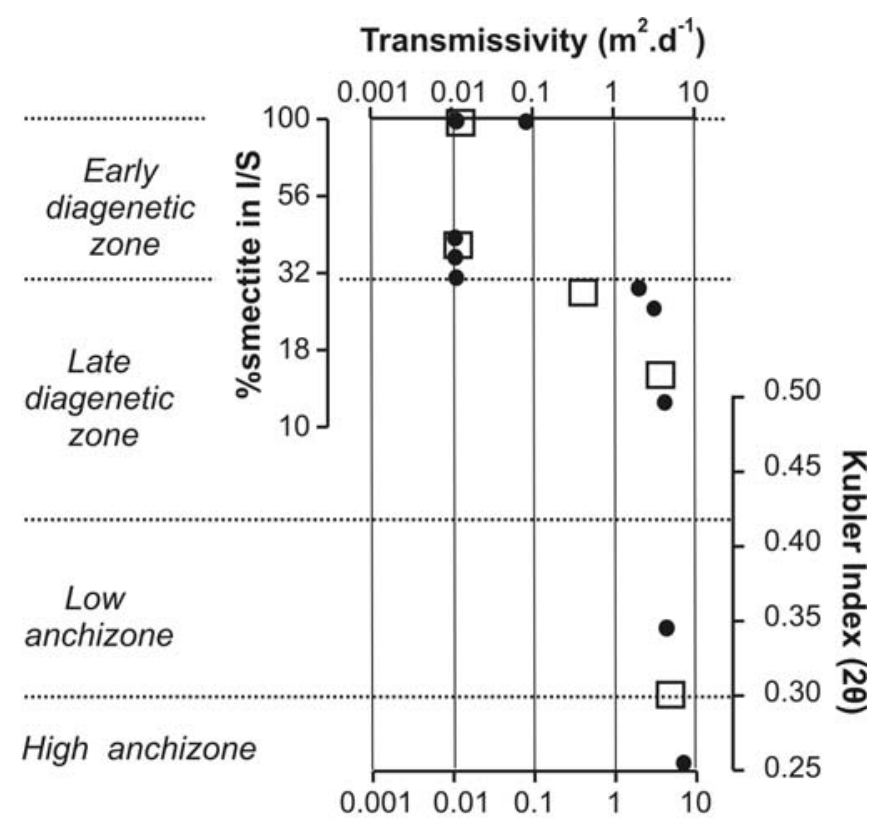

Mean data for each mudstone formation (see Table 5).

- Data from representative boreholes, which have both clay and transmissivity data (see Table 2 and 4 ).

Figure 6 Transmissivity related to degree of low-grade metamorphism of mudstones in Oju/Obi using \%smectite and Kubler Index as indicators.

Where mudstones have been buried and subjected to anchizonal metamorphism, illite dominates the clay mineralogy. Illite has a much higher negative charge than smectite, and therefore binds interlayer ions more closely. Illite does not swell, and often has large crystals (>100 ̊). This makes illitic/micaceous mudstones stable and resistant to weathering (hence the durability of roofing slate). Any fractures at shallow depths within the mudstone will generally remain open. This is clearly observed in the Asu River Group where fractures are 
widespread. The brittleness of illite-dominated mudstones ensure that they are easily fractured. Tectonic stresses, erosional unloading or even the reactivation of hydrofractures could easily give rise to stresses that create the fractures (Singhal \& Gupta 1999).

In Late Diagenetic Zone mudstones, the proportion of illite and smectite layers within I/S is crucial to the development of secondary permeability. Where illite dominates, fractures are likely to remain open and enhance the permeability of the mudstone. However, if mudstones are less mature and high-smectite I/S clays dominate, secondary permeability is unlikely to develop. The exploratory boreholes in the Eze-Aku Shale Formation showed that permeability was greatly enhanced by large fault zones, giving transmissivity values of 1 to 3 $\mathrm{m}^{2} . \mathrm{d}^{-1}$. However, boreholes that did not penetrate large fracture zones had low transmissivity (akin to those in the Awgu Shale).

Variations in transmissivity data from Oju/Obi are therefore explained by considering the extent of low-grade metamorphism. This conceptual model may apply to other mudstone areas.

\section{The presence of thin sandstone and limestone layers}

The presence of interbedded non-mudstone lithologies, ranging from one millimetre to several metres thick, has an important effect on the hydrogeology of mudstone environments. Three test sites were located in areas that had significant sandstone or limestone beds interlayered within the mudstone: Ochingini, Odaleko Adiko and Adum East, all within the Eze-Aku Group. Two others penetrated thin alluvium layers: Itogo and the north Obi traverse. 
Laboratory estimates of hydraulic conductivity and porosity for the sandstone boreholes indicate that fracture flow dominates (MacDonald 2001). Careful examination of core samples indicates thin fractures in many of the sandstone boreholes at about $8-20 \mathrm{~m}$. Pumping tests in these boreholes indicated transmissivity ranging from 0.1 to $1 \mathrm{~m}^{2} \cdot \mathrm{d}^{-1}$ for 5 boreholes (Table 3). Similar shallow fractures have been found subsequently by WaterAid when constructing hand-dug wells.

Thin limestone layers were also found to contain significant ground water in Oju/Obi where fractured. A good example is Ochingini (BGS6) where a thin $(<0.3 \mathrm{~m})$ limestone layer is present within a soft smectite mudstone. A five-hour pumping test indicated transmissivity of about $18 \mathrm{~m}^{2} \cdot \mathrm{d}^{-1}$. Cores from the limestone indicated pervasive fracturing.

Thin sandstone and limestone layers therefore have a significant impact on the local hydrogeological conditions in mudstones. In soft, unaltered mudstones, searching for thin sandstone or limestone layers may be the only reasonable option for ground water supplies to rural communities. Fortunately such interlayers are common in mudstones that have been deposited in deltaic or shallow sea environments. Even deep marine mudstone can contain coarser material and limestone because of turbidites (Reading 1996).

The sustainability of supplies from deeply buried thin sandstone or limestone layers, cannot be assessed from the short pumping tests used in this study to estimate transmissivity. Much longer tests, ground water dating methods, or long term monitoring of pumping yields and water levels are required. Several studies have indicated that recharge through thick clay layers is possible: Rushton (1986) demonstrated that vertical seepage through clay layers was the main mechanism for recharge in thin alluvial aquifers in India; similar mechanisms were 
also found through the London Clay to the Lower Greensand in southern England (Egerton 1994).

\section{Dykes and sills}

Some of the most productive boreholes in $\mathrm{Oju} / \mathrm{Obi}$ penetrated dolerite intrusions found within the soft, smectitic mudstones of the Awgu Shales Formation. Often, dykes and sills are avoided as they rarely contain ground water and often act as impermeable barriers to ground water flow (e.g. Bromley et al. 1994). On the rare occasions that the presence of dykes and sills has been found to increase borehole yields, the main factor has been increased fracturing in the host rocks due to contact metamorphism (Ventriss et al. 1982).

In Oju/Obi, a clear pattern emerges: boreholes that penetrate thick dolerite intrusions (see Table 2) yield significant quantities of ground water (geometric mean transmissivity for 5 boreholes, $13 \mathrm{~m}^{2} \cdot \mathrm{d}^{-1}$ ). Where thinner intrusions (less than $0.5 \mathrm{~m}$ thick) are encountered within the smectite mudstone, transmissivity was slightly enhanced, relative to the mudstone (geometric mean transmissivity for 3 boreholes, $0.17 \mathrm{~m}^{2} \cdot \mathrm{d}^{-1}$ ), but rarely sufficient to support a borehole equipped with a handpump.

The geological logs of the exploratory boreholes contain interesting information about the dolerite (Figure 4). The majority of ground water was not found in the metamorphosed and disturbed mudstone next to the intrusions but within the dolerite, primarily at the contact zone with the host rock. Exploratory boreholes that targeted thick intrusions found that the edges of the dolerite intrusions were characterised by a large number of open fractures. Many of the fractures were lined with millimetre-long zeolite (mesolite) crystals, suggesting precipitation from low temperature, hydrothermal fluids. The other exploratory boreholes targeting 
dolerite encountered much thinner intrusions - some only a few centimetres across. Geological cores indicated that fracturing within thin dolerite intrusions was poorly developed and there was little corresponding zeolite growth within the fractures.

Therefore the presence of large dolerite intrusions, which can be highly fractured within mudstone environments, are excellent targets for village water supplies - particularly in soft smectite mudstones where other usable ground water resources are sparse. Transmissivity alone, however, cannot give reliable information on sustainability - particularly where the inflow to the borehole is from isolated fractures within intrusions with 10s of metres of mudstone between the ground surface and the fractures. The pumping tests within the intrusions were too short ( 5 hours) to indicate barrier effects. Three exploratory boreholes targeting the thick intrusions were completed as production boreholes and equipped with a handpump. The boreholes continue to be a reliable source after 4 years of pumping. Further and more widespread monitoring will help to give more information on sustainability.

\section{Summary and conclusions}

The study of the hydrogeology of the Oju/Obi area has provided an excellent opportunity to examine the hydrogeology of mudstone environments. The research has demonstrated that transmissivity in the upper $40 \mathrm{~m}$ can be sufficient to sustain boreholes with handpumps (success is based on supplying 250 people 25 litres per day). Two aspects are particularly 
important in controlling the transmissivity: low-grade metamorphism and the presence of subordinate lithologies, particularly dolerite intrusions (Figure 7).

The results of this research are being used by WaterAid in Oju /Obi to develop village water supplies. Simple guidelines have allowed more than 100 successful village water supplies to be developed in an area that was thought not to contain any significant extractable ground water. The illite dominated mudstones are distinguished using electromagnetic techniques (MacDonald et al. 2001). Dolerite intrusions within smectite mudstones continue to be targeted using magnetic profiling. Sandstone layers are being developed using hand-dug wells after being identified with electromagnetic methods.

Continued research of mudstone environments is central to helping provide safe reliable water supplies to many of the poorest communities in Africa. Although this research has demonstrated successful boreholes can be drilled in mudstone environments, careful monitoring and further research is necessary to ensure sustainability and reliability. 

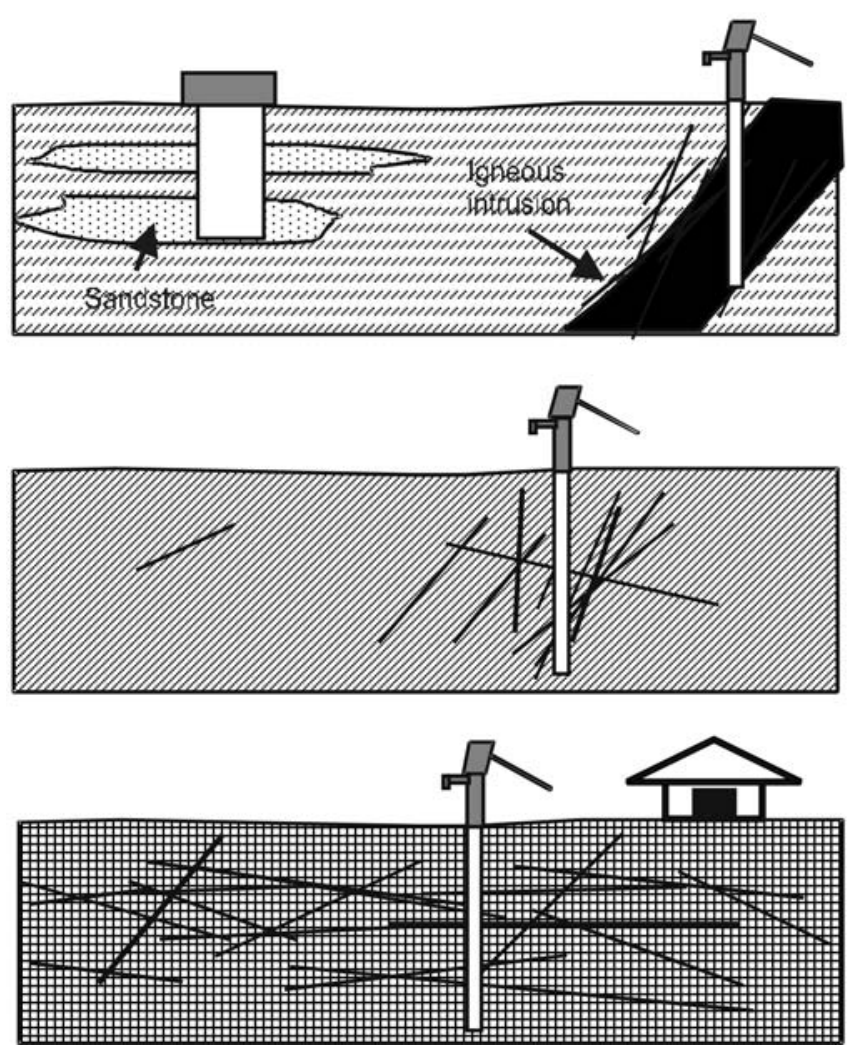

In smectite dominated mudstones there is no usable water within the clay. The only water in these areas is found in thin sandstone layers or small igneous intrusions

If the mudstone has been subjected to burial and altered to I/S clay, usable groundwater can be found in large fractures and faults. Faults and fractures however, may be far apart. Where I/S clays have a high proportion of smectite, however, little groundwater may be found, even in large faults.

Where mudstones have been altered to comprise illite clays fractures are widespread and groundwater is easily found.

Figure 7 Schematic representation of the main factors affecting ground water occurrence in mudstone environments.

\section{Acknowledgements}

This paper is published with permission of the Executive Director, British Geological Survey (NERC). The work was carried out with the assistance of many people in Nigeria. Particular thanks to Steve Sugden, Kitka Goyol and Vincent Edu of WaterAid for their help with fieldwork and Peter Ball and Peter Rastell for proficient drilling. Prof John Barker of UCL and Dr John Bloomfield of BGS are thanked for their helpful comments on the manuscript; thanks also to the Dr Tamie Weaver and another anonymous referee. The work was funded by the U.K. Department for International Development (project number CNTR 960023A). 


\section{References}

Akande, S.O., and B.D. Erdtmann. 1998. Burial metamorphism (thermal maturation) in Cretaceous sediments of the Southern Benue Trough and Anambra Basin, Nigeria. Bulletin of the American Association of Petroleum Geologists 82: 1191-1206.

Barker, J.A. 1985. Generalised well-function evaluation for homogeneous and fissured aquifers. Journal of Hydrology 76: 143-154.

Barker, J.A., and J.H. Black. 1983. Slug tests in fissured aquifers. Water Resources Research 19: $1558-1564$.

Barker, J.A., and D.M.J. Macdonald. 2000. A manual for BGSPT: programs to simulate and analyse pumping tests in large-diameter wells. British Geological Survey Technical Report $\mathrm{WC} / 00 / 17$.

Barker, J.A., and R. Herbert. 1989. Nomograms for the analysis of recovery tests on largediameter wells. Quarterly Journal of Engineering Geology 22: 151-158.

Benkhelil, J. 1989. The origin and evolution of the Cretaceous Benue Trough. Journal of African Earth Sciences 8: 251-282.

Black, J.H. 1985. The interpretation of slug tests in fissured rocks. Quarterly Journal of Engineering Geology 18: 161-171.

Black, M. 1998. Learning what works: a 20 year retrospective view on international water and sanitation cooperation. Washington: UNDP-Worldbank Water and Sanitation Programme.

Bromley, J., B. Mannstrom, D. Nisca, and A. Jamtlid. 1994. Airborne geophysics: application to a ground water study in Botswana. Ground Water 32: 79-90.

Capuano, R.M., and R.Z. Jan. 1996. In situ hydraulic conductivity of clay and silty-clay fluvial-deltaic sediments, Texas Gulf Coast. Ground Water 34: 545-551.

Davies, J., and A.M. MacDonald. 1999. The groundwater potential of the Oju/Obi area, eastern Nigeria. British Geological Survey Technical Report WC/99/32.

Desbarats, A.J., M.J. Hinton, C.E. Logan, and D.R. Sharpe. 2001. Geostatistical mapping of leakance in a regional aquitard, Oak Ridges Moraine area, Ontario, Canada. Hydrogeology Journal 9: 79-96.

Egerton, R.H.L. 1994. Recharge of the Lower Greensand aquifer at Slough, England. Quarterly Journal of Engineering Geology 27: S57-72..

Gautschi, A. 2001. Hydrogeology of a fractured shale (Opalinus Clay): implications for deep geological disposal of radioactive wastes. Hydrogeology Journal 9: 97-107.

Geological Survey of Nigeria. 1957a. Nigeria 1:250 000 Geological Series, Makurdi Sheet 64. Kaduna: Geological Survey of Nigeria.

Geological Survey of Nigeria 1957b. Nigeria 1:250 000 Geological Series, Ogoja Sheet 73. Kaduna: Geological Survey of Nigeria.

Gerber, R.E., J.I. Boyce, and K.W.F. Howard. 2001. Evaluation of heterogeneity and fieldscale groundwater flow regime in a leaky till aquitard. Hydrogeology Journal 9: 60-78. 
Hower, J., E.V. Eslinger, M.E. Hower, and E.A. Perry. 1976. Mechanism of burial metamorphism of argillaceous sediment: 1. Mineralogical and chemical evidence. Bulletin of the Geological Society of America 87: 725-737.

Kisch, H.J. 1991. Illite crystallinity: recommendations on sample preparation, X-ray diffraction settings and interlaboratory standards. Journal of Metamorphic Geology 6: 665670 .

Kruseman, G.P., and N.A. deRidder. 1990. Analysis and evaluation of pumping test data. International ILRI Publication 47. The Netherlands: Institute for Land Reclamation and Improvement.

MacDonald, A.M. 2001. Community water supplies from mudstones Ph.D. Diss., Department of Geological Sciences, University College London.

MacDonald, A.M., J. Davies, and R.J. Peart. 2001. Geophysical methods for locating groundwater in low permeability sedimentary rocks: examples from southeast Nigeria, Journal of African Earth Sciences 32: 115-131.

MacDonald, A.M., and J. Davies. 2000. A brief review of groundwater for rural water supply in sub-Saharan Africa. British Geological Survey Technical Report WC/00/33.

Mace, R.E. 1999. Estimation of hydraulic conductivity in large-diameter, hand-dug wells using slug-test methods. Journal of Hydrology 219: 34-45.

Merriman, R.J. and D.R. Peacor. 1999. Very low-grade metapelites: mineralogy, microfabrics and measuring reaction progress. In Low grade metamorphism, ed. M. Frey, and D. Robinson, 10-60. Oxford: Blackwell Science.

Miller, W., R. Alexander, N. Chapman, I. McKinley, and J. Smellie. 2000. Geological Disposal of Radioactive Waste and Natural Analogues. Amsterdam: The Netherlands.

Moore, D.M., and R.C. Reynolds. 1997. X-Ray Diffraction and the Identification and Analysis of Clay Minerals, Second Edition. New York: Oxford University Press.

Moore, G.K. 1997. Quantification of ground-water flow in fractured rock, Oak Ridge, Tennessee, Ground Water 35: 478-482.

Neuzil, C.E. 1986. Groundwater flow in low-permeability environments, Water Resources Research 22: 145-150.

Neuzil, C.E. 1994. How permeable are clays and shales? Water Resources Research 30: 145150 .

Ofoegbu, C.O. 1985. A review of the geology of the Benue Trough, Nigeria. Journal of African Earth Sciences 3: 283-291.

Ojoh, K.A. 1990. Cretaceous dynamic evolution of the southern part of the Benue Trough (Nigeria) in the equatorial domain of the South Atlantic, Stratigraphy, basin analysis and palaeo-oceanography. Centres Recherché Exploration-Production Elf-Aquitaine, Bulletin 14, 419-442.

Papadopulos, I.S., and H.H. Cooper. 1967. Drawdown in a well of large diameter. Water Resources Research 3: 241-244.

Reading, H.G. 1996. Sedimentary environments: processes, facies and stratigraphy. Oxford: Blackwell Science. 
Remenda, V. 2001. Preface, theme issue on confining units. Hydrogeology Journal 9: 3-4.

Reynolds, R.C., and R.C. Reynolds. 1996. Description of Newmod-for-Windows ${ }^{\text {TM }}$. The calculation of one-dimensional X-ray diffraction patterns of mixed layered clay minerals. $\mathrm{R}$ C Reynolds Jr., 8 Brook Road, Hanover, NH.

Rushton, K.R. 1986. Vertical flow in heavily exploited hard rock and alluvial aquifers, Ground Water. 24: 610-608.

Sen, M.A., and M.A.W. Abbot. 1991. Hydrogeological investigation of a fault in clay. Quarterly Journal of Engineering Geology 24: 413-426.

Singhal, B.B.S., and R.P. Gupta. 1999. Applied Hydrogeology of fractured rocks. Dordrecht: Kluwer Academic Publishers.

Snow, D.T. 1968. Rock fracture spacings, openings and porosities. Journal Soil Mechanics, Foundation Divisions, Proceedings of the American Society of Civil Engineers 94: 73-91.

Struckmeir, W.F. and Margarat, J. 1995. Hydrogeological maps: a guide and standard legend. International Contributions to Hydrogeology Volume 17, International Association of Hydrogeologists. Hanover: Heise.

Tucker, M. 1980. The Field Description of Sedimentary Rocks, The Geological Field Guide Series. Chichester: John Wiley \& Sons.

van der Kamp, G. 2001. Methods for determining the in situ hydraulic conductivity of shallow aquitards - an overview. Hydrogeology Journal: 9, 5-16.

Ventriss, H.B., D.B. Collett, and D.W. Boyd. 1982. Relationship between groundwater occurrence and a dolerite dyke in the Northampton area of Western Australia, Proceedings of the AWRC Conference, Groundwater in fractured rock, 217-227.

Vicente, M.A., F. Elsass, E. Molina, and M. Robert. 1997. Palaeoweathering in slates from the Iberian Hercynian Massif (Spain): investigation by TEM of clay mineral signatures. Clay Minerals 32: 435-451. 